\title{
Notes on mammals of the Ngoc Linh Nature Reserve (Vietnam, Kon Tum Province)
}

\author{
Alexei V. Abramov, Viatcheslav V. Rozhnov \& Petr N. Morozov

\begin{abstract}
Two biological surveys of the highly elevated area of Mount Ngoc Linh (the Ngoc Linh Nature Reserve) have revealed 12 mammal species: Euroscaptor cf. klossi, Rhinolophus affinis, Harpiola isodon, Mus pahari, Chiropodomys gliroides, Niviventer fulvescens, Niviventer langbianis, Tamiops maritimus, Dremomys rufigenis, Crocidura attenuata, and two undetermined Crocidura species. A few further species, such as Ratufa bicolor, Capricornis milneedwardsii, Muntiacus cf. muntjac, Lamprogale lasiotis and Nomascus cf. gabriellae are reported from field observations.
\end{abstract}

KEY WORDS: mammals, Ngoc Linh, Central Highlands, Vietnam.

AlexeiV. Abramov [aav@aa2510.spb.edu], Zoological Institute, Russian Academy of Sciences, Universitetskaya nab. 1, Saint Petersburg 199034, Russia; Viatcheslav V. Rozhnov [rozhnov@sevin.ru] and Petr N. Morozov [pnmorozov@yandex.ru],A.N. Severtsov Institute of Ecology and Evolution, Russian Academy of Sciences, Leninskii pr. 33, Moscow 119071, Russia.

\section{Заметки о млекопитающих заповедника Нгок Линь (Вьетнам, провинция Контум)}

\author{
А.В. Абрамов, В.В. Рожнов, П.Н. Морозов
}

\begin{abstract}
РЕЗЮМЕ. В результате исследований в горном массиве Нгок Линь на территории природного заповедника Нгок Линь было добыто 12 видов млекопитающих: Euroscaptor cf. klossi, Rhinolophus affinis, Harpiola isodon, Mus pahari, Chiropodomys gliroides, Niviventer fulvescens, Niviventer langbianis, Tamiops maritimus, Dremomys rufigenis, Crocidura attenuata, и два пока неопределенных вида землероек-белозубок рода Crocidura. На основании визуальных наблюдений установлено обитание Ratufa bicolor, Capricornis milneedwardsii, Muntiacus cf. muntjac, Lamprogale lasiotis и Nomascus cf. gabriellae.
\end{abstract}

КЛЮЧЕВЫЕ СЛОВА: мЛекопитающие, Нгок Линь, Вьетнам.

\section{Introduction}

The Mount Ngoc Linh (ca. 2,598 m above sea level) situated at the northwestern margin of Kontum Massif is the highest point of the Truong Son (or Annamite) Range in central Vietnam (Fig. 1). The Ngoc Linh Nature Reserve was established in 1986 for conservation of the montane evergreen forest. This part of the Central Highlands includes a complex mosaic of volcanic basalts, granites and sedimentary substrates with wet montane evergreen hardwood and conifer forests. Ngoc Linh is actually split up into two nature reserves: one in Quang Nam Province and another in Kon Tum Province. These two reserves cover the peak and slopes of Mount Ngoc Linh and neighboring high mountain peaks. Ngoc Linh (Kon Tum) Nature Reserve covers 41,240 ha in Dac Glei and Dac To districts, Kon Tum Province. Ngoc Linh (Quang Nam) Nature Reserve covers 18,430 ha, in Tra My district, Quang Nam Province.

Recent biological surveys showed that this high altitude has also provided the conditions for evolving a unique community of animal and plant species that is completely confined to the Ngoc Linh high Mts. Extensive surveys of mammals by the Forest Inventory and Planning Institute (Hanoi) in cooperation with the BirdLife International in Ngoc Linh (Kon Tum) Nature Reserve were conducted in 1996 and 1998. In total of 52 mammal species were recorded for Ngoc Linh (Kon Tum) Nature Reserve, of which 20 are red-listed (Le Trong Trai et al., 1999).

Two complex biodiversity surveys of the Ngoc Linh (Kon Tum) Nature Reserve were carried out in 2004 and 2004 by the Russian-Vietnamese Tropical Centre. One of their aims was an inventory of small mammal species diversity of the region at hand.

\section{Material and methods}

Field works were conducted from 24 March to 20 April in 2004 and from 19 March to 9 April in 2006. The expedition base camp was situated on western slope of Mount Ngoc Linh (Ngoc Linh Commune, Dac Glei District of Kon Tum Province; 15 04'43' N, 


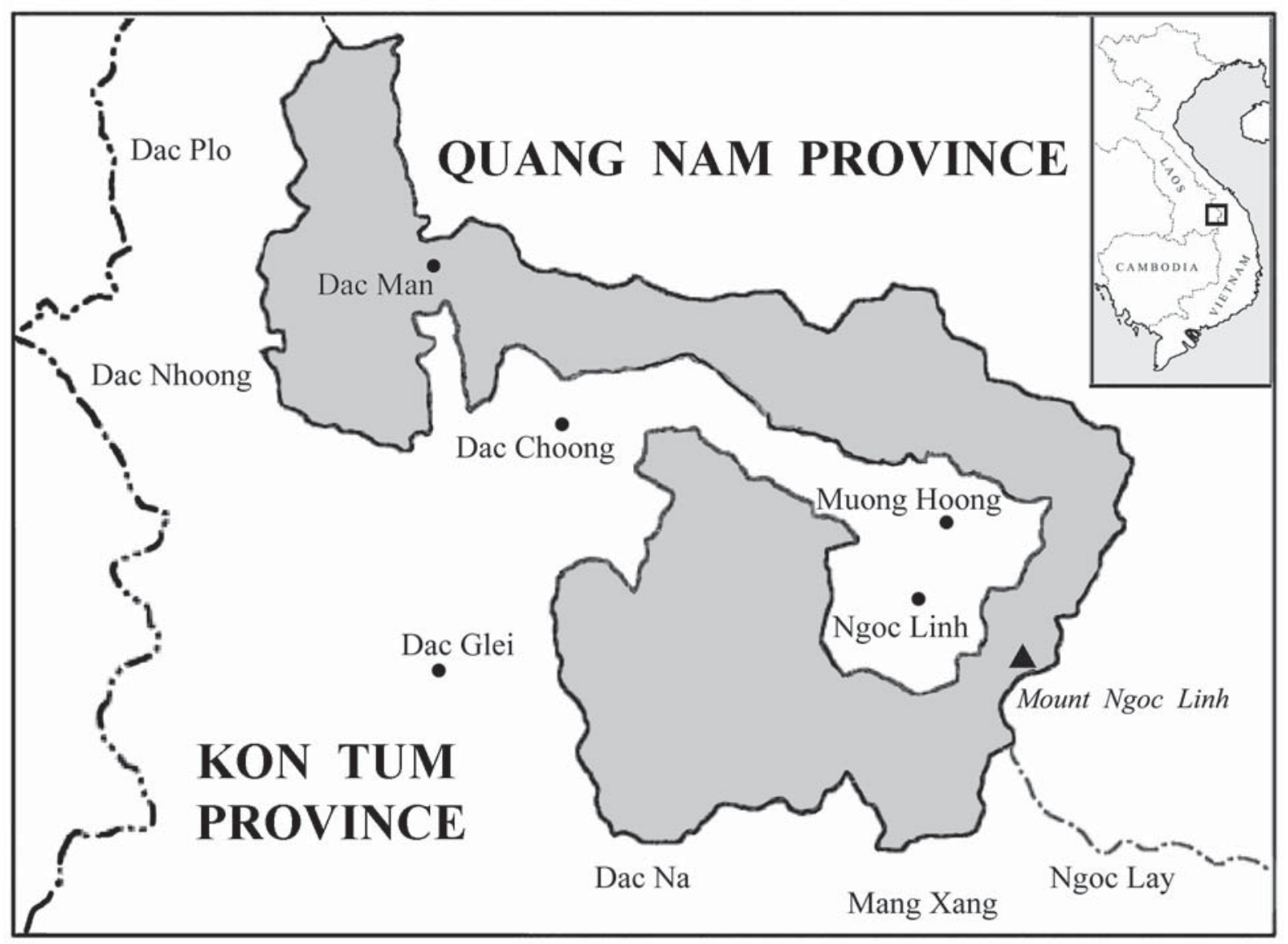

Figure 1. Map of Vietnam showing the location of the Ngoc Linh (Kon Tum) Nature Reserve.

$\left.107^{\circ} 57^{\prime} 04^{\prime \prime} \mathrm{E}\right)$, at the elevation of $1650 \mathrm{~m}$ above sea level. We surveyed different biotopes around the summit of Ngoc Linh Mt., in the radius of $2-3 \mathrm{~km}$ of the base camp.

Different types of traps were used as follows: (1) Large $(11 \times 11 \times 25 \mathrm{~cm})$ cage live-traps and small $(7 \times 7 \times 20$ $\mathrm{cm})$ aluminium box live-traps, each with a bait of a foam-rubber piece saturated with vegetable oil to be replaced every 2-3 days; (2) Pitfall traps, i.e. plastic buckets of different sizes $(40 \mathrm{~cm}$ deep $\times 30 \mathrm{~cm}$ in diameter, $18 \times 20$, and $14 \times 15$ ), buried flush with the ground surface. The bats were trapped by $10 \times 2 \mathrm{~m}$ and $12 \times 2$ m nylon mist nets.

Main forest types occurring in the study site were surveyed, with an altitudinal range of 1700-2530 m above sea level being covered. In total of 2190 trapnights in 2004 and 400 trap-nights in 2006 were conducted. The pitfall traps were set up for 290 trap-nights in 2004 and 352 trap-nights in 2006.

The standard external body measurements (head and body length, tail length, hind foot length, ear length) were taken. For bats, the forearm length was also measured. Weight was taken in grams. Except for voucher specimens, all trapped mammals were released as far as at least $1-2 \mathrm{~km}$ apart from the trap-lines to eliminate repeated captures. The voucher specimens are retained in the Zoological Institute Russian Academy of Sciences, Saint-Petersburg and the Zoological Museum of Moscow University (ZMMU).

\section{Results}

Based on the trapped specimens an annotated list of 12 mammal species of the Mount Ngoc Linh is presented here. In addition, 5 species are reported reasoning from field observations (field seeing, footprints etc.). Each reported species is provided with relevant taxonomic notes alongside with distributional and habitat data.

\section{ORDER SORICOMORPHA Gregory, 1910 Family SORICIDAE Fischer, 1817 Genus Crocidura Wagler, 1832 Crocidura spp.}

The taxonomy of Crocidura in SE Asia remains poorly understood (Jenkins, 1982; Heaney \& Timm 1983; Jenkins \& Smith, 1995). The Vietnamese Crocidura were reviewed by Heaney \& Timm (1983), who compiled the information for the three species, C. fuliginosa, C. attenuata, and C. horsfiledi indochienensis, known from the country at that time. Yet, there are 


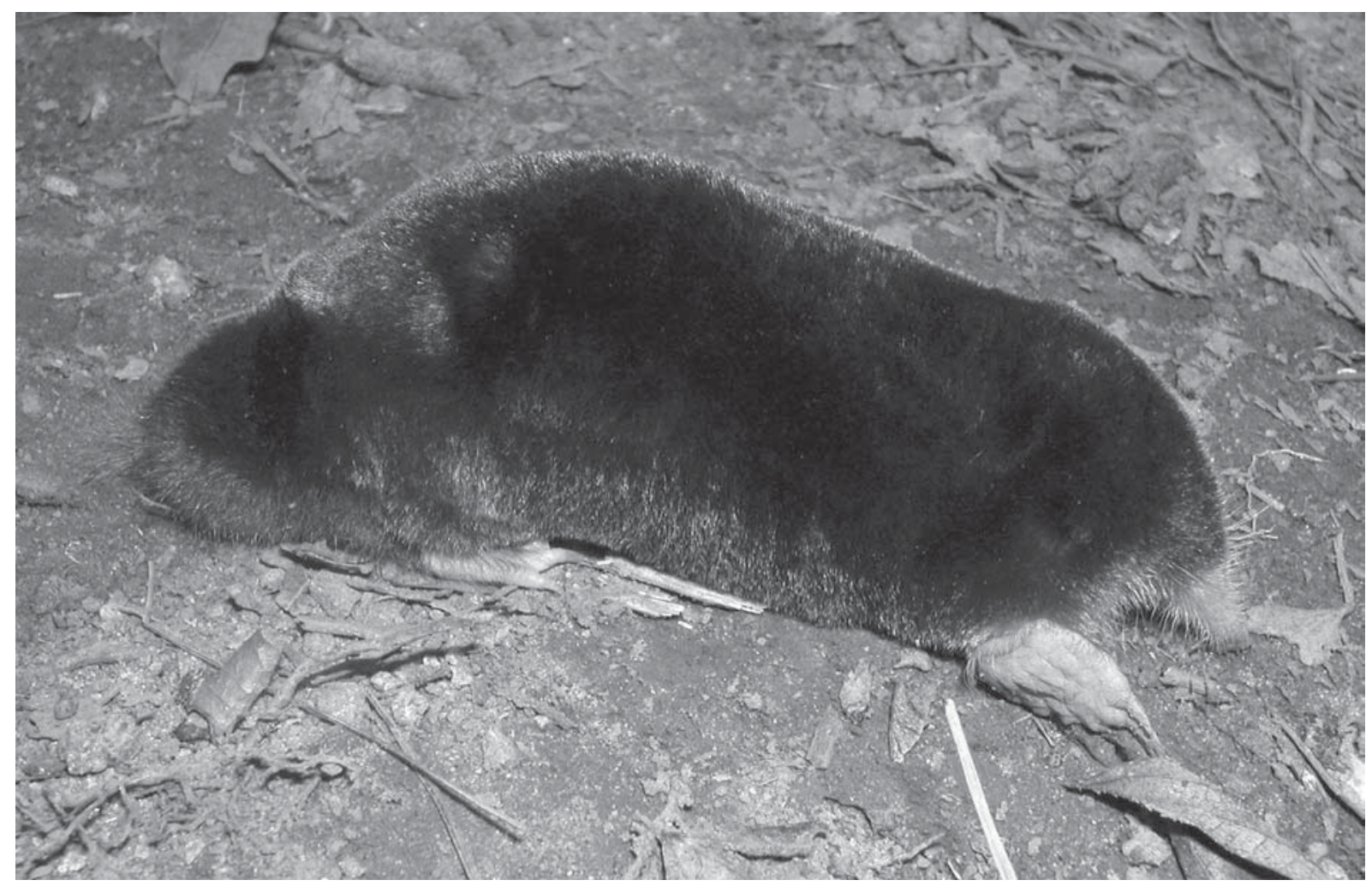

Figure 2. Euroscaptor cf. klossi, female.

more species of Crocidura and other shrews to be discovered in that region (Lunde et al., 2003, 2004).

The fauna of shrews of Ngoc Linh area has not been studied properly. Earlier, the single species C. fuliginosa was observed in Mang Xang Commune (Le Trong Trai et al., 1999). During our surveys, three forms of white-toothed shrews of the genus Crocidura were collected by pitfall traps. One of them, collected at elevations of 1600-1700 m above sea level, is supposedly Crocidura attenuata Milne-Edwards, 1872. Two others have not yet been identified and are likely to represented new taxa. A large and long-tailed form resembled C. fuliginosa was recorded at the elevations of 2000-2530 $\mathrm{m}$ above sea level, and a small shrew being probably close to the indochienensis-wuchinensis species complex was found at various elevations ranging from 1650 to $2350 \mathrm{~m}$ above sea level. A revision of these forms is currently being prepared by Abramov, Rozhnov and Paula Jenkins from the Natural History Museum, London.

Family TALPIDAE Fischer, 1817

Genus Euroscaptor Miller, 1940

Euroscaptor cf. klossi (Thomas, 1929)

Fig. 2.

In 2004, numerous traces of the mole activity (old and fresh mounds) were observed on grassy glades and bushes nearby the base camp. Fresh mounds were mainly located near domestic buffalo' pats of dung. These pats represent areas with high density of earthworms and coprophagous insects (such as dung beetles) and therefore they were attractive for moles. During 2006 survey, we found mole tunnels mining the upper ground layer and mulch in different forest habitats at the elevations of 1700-2200 m above sea level. Two adult females were caught by the middle-sized pitfall traps set under the mole tunnels in April 7, 2006 at the elevation of $1800 \mathrm{~m}$ above sea level. External measurements areas follows: head and body length $120-123 \mathrm{~mm}$, tail length $15 \mathrm{~mm}$.

During previous surveys, the mole (identified as Talpa micrura) was recorded from Mang Xang Commune southward of Mount Ngoc Linh (Le Trong Trai et al., 1999).

Species assignments of the Vietnamese moles and their species limits are tentative. A taxonomic status of Ngoc Linh moles is questionable too. The majority of former checklists (Corbet, 1978; Lekagul \& McNeely, 1988; Corbet \& Hill, 1992) placed all the moles from Indochina to Talpa (or Euroscaptor) micrura. However, according to recent research (Yoshiyuki, 1988; Hutterer, 2005), the name micrura should be assigned to the moles from the Eastern Himalayas and Malaysian Peninsular. The moles from Central Vietnam and Ngoc Linh area may belong to Euroscaptor klossi. 


\author{
ORDER CHIROPTERA Blumenbach, 1779 \\ Family RHINOLOPHIDAE Gray, 1825 \\ Genus Rhinolophus Lacépède, 1799 \\ Rhinolophus affinis Horsfield, 1823
}

This widespread Indomalayan species of the horseshoe bats is distributed in mountainous territories throughout Northern and Central Vietnam. In Vietnam, it has been reported from Lao Cai, Lang Son, Ninh Binh and Lam Dong Provinces (Dang Huy Huynh et al., 1994). This species is found in Vu Quang Nature Reserve (Kuznetsov et al., 2001) and on Lang Bian (Da Lat) Plateau (Borissenko \& Kruskop, 2003). It was also recorded from Quang Nam Province on the east slope of Ngoc Linh Mt. (Tordoff et al., 2000).

In evening time (March 25, 2004), a single adult male was caught near its shelter (a small grotto on the bank of artificial drain) nearby the base camp, at the elevation of $1700 \mathrm{~m}$ above sea level.

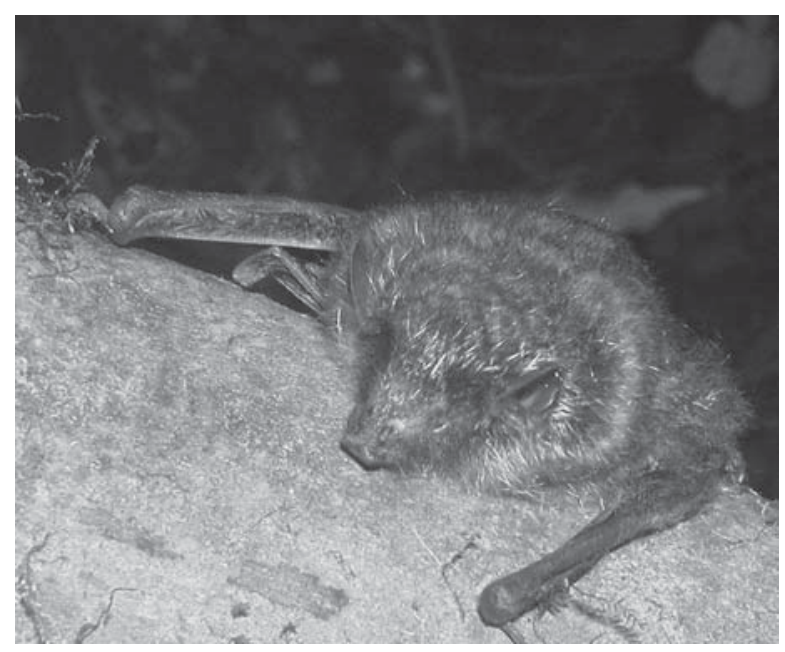

Figure 3. Harpiola isodon, male (ZMMU S-180001).

Family VESPERTILIONIDAE Gray, 1821

Genus Harpiola Thomas, 1915

Harpiola isodon Kuo, Fang, Csorba \& Lee, 2006

Fig. 3.

This new species of tube-nosed bat was recently described from Taiwan (Kuo et al., 2006). Another species of this genus, $H$. grisea Peters, 1872, is known only after two specimens from India (Tate, 1941; Bhattacharyya, 2002).

A subadult male of the tube-nosed bats was collected on March 28, 2006, in the evergreen forest at the elevation of $2250 \mathrm{~m}$ above sea level. The bat was captured by nylon mist net, which was set up for ornithological research. After the examination of this specimen in the Zoological Museum of the Moscow State University, a whole complex of the specific Harpiola features was revealed (Kruskop et al., 2006). Moreover, this specimen clearly corresponds to the description of $H$. isodon, representing hence the first record of the species from Vietnam and the first record outside the type locality.

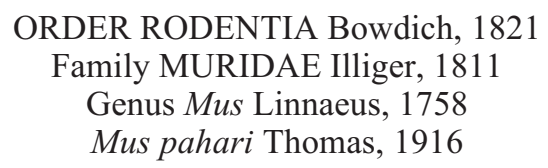

This Indochinese shrew-like mouse is widespread in Vietnam, from north-western provinces to Kon Tum Province (Dang Huy Huynh et al., 1994; Lunde \& Nguyen Truong Son, 2001). This is a rather large mouse, of which distinctive features are long-nosed shrew-like head and spiny dorsum.

Two specimens were caught in 2004 nearby the base camp. Both were collected from the glade with Albizia lucidior, near fallen trees, at the elevation of $1700 \mathrm{~m}$ above sea level. The adult male was caught by live-trap baited with alive beetle larvae on April 7, and the subadult male was trapped by pitfall trap on April 10. This is the first record of the species from the Ngoc Linh Nature Reserve.

Genus Chiropodomys Peters, 1869

Chiropodomys gliroides (Blyth, 1856) Fig. 4.

The species is widely distributed in the Indomalayan region (Musser \& Carleton, 2005). Dang Huy Huynh et al. (1994) mapped its localities in Central Vietnam (Dac Lac and Kon Tum provinces), but the species has also been collected farther northward, from Ha Tinh Province (see Musser \& Carleton, 2005) and in Ha Giang Province (Lunde et al., 2003).

In 2004, we collected three specimens of the Indomalayan pencil-tailed tree mouse. They were caught in cage traps set up on woody lianas and tree branches approximately at $2-2.5 \mathrm{~m}$ above the ground. Adult female was caught in the secondary forest at the elevation of $1700 \mathrm{~m}$ above sea level. Two specimens (male and female, probably a couple) were caught in the pine forest predominanted with Pinus dalatensis at the elevation of $2000 \mathrm{~m}$ above sea level, on April 2 and 12 accordingly. This is first record of the species for the Ngoc Linh Nature Reserve.

Genus Niviventer Marshall, 1976

Niviventer fulvescens (Gray, 1847)

We collected three specimens in 2004. The Indomalayan niviventers were caught by cage traps set up on horizontal tree branches at 1.5-2 $\mathrm{m}$ above the ground, at the elevations of 1900-2000 $\mathrm{m}$ above sea level. This is first record of the species for the Ngoc Linh Nature Reserve.

Niviventer langbianis (Robinson \& Kloss, 1922)

A single specimen was collected in 2006. The specimen was caught by the cage-trap set up on the tree branch at $2 \mathrm{~m}$ above the ground, at the elevation of 


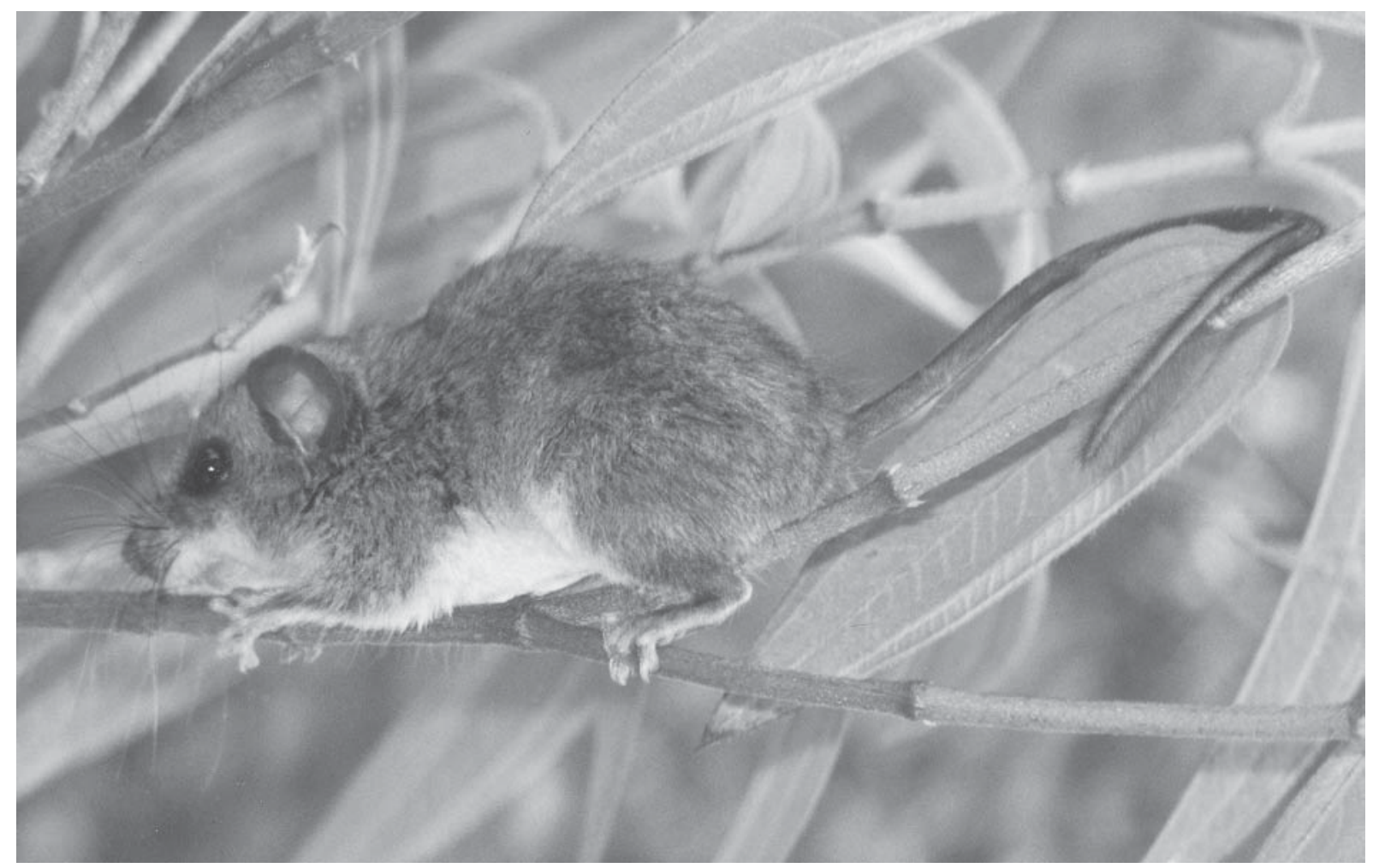

Figure 4. Chiropodomys gliroides, female.

$1700 \mathrm{~m}$ above sea level. This is first record of the species for the Ngoc Linh Nature Reserve.

\section{Family SCIURIDAE Fischer, 1817 Genus Tamiops Allen, 1906 \\ Tamiops maritimus (Bonhote, 1900)}

A single specimen (a subadult female) was collected on April 12, 2004. The specimen was captured by the cage trap set on the horizontal tree branch at $3 \mathrm{~m}$ above the ground. The trap line was set up in the primary forest predominated with Pinus dalatensis at the elevation of $2000 \mathrm{~m}$ above sea level. This is first record of the species for the Ngoc Linh Nature Reserve.

\section{Genus Ratufa Gray, 1867 \\ Ratufa bicolor (Sparrman, 1778)}

We did not collect this species. In 2004, the black giant squirrels were often observed at the elevations of 1900-2000 m above sea level, mostly in the areas with large stands of Pinus dalatensis.

Genus Dremomys Heude, 1898

Dremomys rufigenis (Blanford, 1878)

The red-checked squirrel is distributed throughout Vietnam, southward to Tay Ninh and Dong Nai provinces (Dang Huy Huynh et al., 1994; Kuznetsov, 2006). In Ngoc Linh Nature Reserve, this species was previously recorded from Mang Xang Commune (Le Trong Trai et al., 1999).
The only voucher specimen we collected was taken on April 1, 2006. A dead specimen was found in the local stone crash-rap (Fig. 5) set up in the scrub near a small stream at the elevation of $1700 \mathrm{~m}$ above sea level.

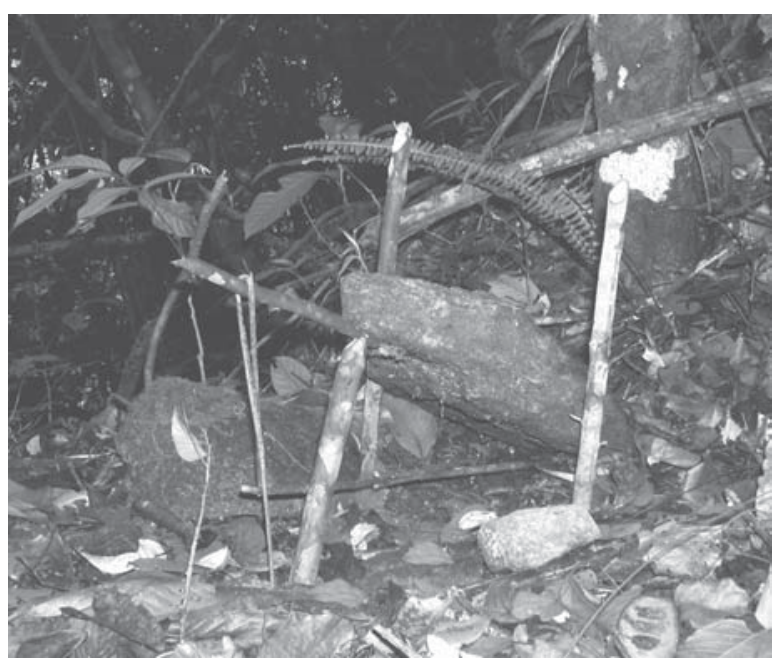

Figure 5. Local stone crash-trap.

ORDER ARTIODACTYLA Owen, 1848

Family BOVIDAE Gray, 1821

Genus Capricornis Ogilby, 1837

Capricornis milneedwardsii David, 1869

The serow known from Indochina and Vietnam was formerly considered as Capricornis sumatraensis (Dang 
Huy Huynh et al., 1994; Corbet \& Hill, 1992; Kuznetsov, 2006). Recently, Grubb (2005) raised milneedwardsii to the status of full species.

We found evidences of the presence of this species in the upper zone of Ngoc Linh Mt. Numerous tracks, trails, dropping and shelters of the serows were recorded at the elevations $2400-2530 \mathrm{~m}$ above sea level, in the dense thickets of Rhododendron and Vaccinium. It seems the serows are still quite abundant here despite a high hunting press.

Family CERVIDAE Goldfuss, 18290

Genus Muntiacus Rafinesque, 1815

Muntiacus cf. muntjak (Zimmermann, 1780)

Tracks and dropping belonging to muntjacs were occasionally found in the broadleaf evergreen forest at the elevations of 1900-2200 m above sea level. Members of the expedition observed the running muntjac some $2 \mathrm{~km}$ northeastern of the base camp at day time on March 27, 2004. A small size and light coloration of the observed animal suggested that it would be the red muntjac, Muntiacus muntjak.

The identification of hunting trophies (Le Trong Trai et al., 1999) increased the known ranges of the recently discovered Giant muntjac, Muntiacus vuquangensis (Tuoc et al., 1994), and the Truong Son muntjac, Muntiacus truongsonensis (Giao et al., 1997), which now includes the Ngoc Linh Nature Reserve (Dac Man, Dac Plo and Mang Xang communes). We did not have any records for these rare species.

\section{ORDER CARNIVORA Bowdich, 1821 \\ Family MUSTELIDAE Fischer, 1817 Genus Lamprogale Ognev, 1928 \\ Lamprogale lasiotis (Temminck, 1892)}

A taxonomic status of the yellow-throated marten follows Rozhnov (1995a, b). Rozhnov (1995b) placed the yellow-throated martens in the genus of it own, Lamprogale, separated from Martes (see also Pocock, 1936). Based on morphological differences, Rozhnov (1995a) suggested that flavigula (the north part of the range) and lasiotis (the south part of the range) deserve the status of full species. He proposed the rank of superspecies for the taxon and considered L. flavigula, L. lasiotis and L. gwatkinsii as allospecies. In Vietnam, L. flavigula is distributed in north provinces (Tonkin) and North Annam, whereas L. lasiotis is distributed in the remaining territory of Vietnam, southward of Hai Van Pass (see Dao Van Tien, 1985; Rozhnov, 1995a).

The yellow-throated marten was recorded (as Martes flavigula) for the Ngoc Linh Nature Reserve (Lo Xo Pass in Dac Man Commune) during the 1998 survey (Le Trong Trai et al., 1999). In 2006, the yellowthroated marten was observed few times in upper zone of Ngoc Linh Mt. Two individuals were observed by M. Kalyakin in the primary forest at the elevation 2350 $\mathrm{m}$ above sea level at morning of March 29, 2006. The same day Phan Luong observed a group of three indi- viduals in the forest near the top of Ngoc Linh at 2500 $\mathrm{m}$ above sea level.

\author{
ORDER PRIMATES Linnaeus, 1758 \\ Family HYLOBATIDAE Gray, 1871 \\ Genus Nomascus Miller, 1933 \\ Nomascus cf. gabriellae (Thomas, 1909)
}

During 2004, we did not find any evidences for the presence of gibbons in the studied area. However, in April 2006, gibbon songs were heard few times in subarea of the summit of Ngoc Linh Mt., at the elevation 2100-2500 m above sea level. During international surveys conducted in April-May 1996 and MarchMay 1998, gibbon songs were also recorded in Ngoc Linh Commune, SE of the Ngoc Linh (Kon Tum) Nature Reserve (Le Trong Trai et al., 1999). No gibbons were recorded during the field survey conducted in the adjacent Ngoc Linh (Quang Nam) Nature Reserve on March-June 1999 (Tordoff et al., 2000).

The species identification of gibbons inhabiting Ngoc Linh Mt. is provisional. Le Trong Trai et al. (1999) listed the gibbons from Ngoc Linh Nature Reserve as Hylobates gabriellae. According to Geissmann et al. (2000, 2003), the Central Vietnam (from Quang Tri to Kon Tum provinces) may represent a transition zone between the southern white-cheeked gibbon, N. leucogenys siki, and the yellow-cheeked gibbon, $N$. gabriellae, and possible hybrids as well. Recently, Groves (2005) separated Nomascus siki from leucogenys and gabriellae.

\section{Discussion}

A preliminary inventory of the mammal fauna of Ngoc Linh (Kon Tum) Nature Reserve was conducted by Le Trong Trai et al. (1999). In total of 52 mammal species were recorded from this area, including a number of threatened and endangered species. However, it is necessary to note that this mammal list was mainly based on interviewing forest-protection staff and local authorities, as well as on field sightings. As a result, small mammals were almost absent from this list. Furthermore, these surveys covered wide territories of the Nature Reserve but did not go to details. Only six species of mammals were recorded from the area of Mount Ngoc Linh in that report (Le Trong Trai et al., 1999: Appendix 2).

Our survey is a first attempt to inventory small mammals of Mount Ngoc Linh Most of the recorded species represents new distributional findings for the Ngoc Linh (Kon Tum) Nature Reserve and also for Vietnam. The inventory of mammals of the Ngoc Linh Mountains is far from complete. Beyond doubts, the list of mammal will be enlarged, for example, after studying the carnivores. Additional research of bats and insectivores are also required.

The fauna of summit of Mount Ngoc Linh is characterized by a high level of endemism. Bird and butterfly 
communities of this sub-area are similar to those of northern and north-western Vietnam. The two newly described bird species, two endemic species and several endemic sub-species have been found here (see Eames et al., 1999a, b; Eames, 2002). A new species of frogs was described from this area in 2005 (Orlov, 2005). The discovery of an endemic and recently unknown to science mammal species is still possible in this unique area.

ACKNOWLEDGMENTS. Our field studies in Vietnam were possible due to the support of the Russian-Vietnamese Tropical Centre and the Russian Academy of Sciences. We thank Phan Luong, A.N. Kuznetsov, M.V. Kalyakin and all expedition members for their great help and scientific expertise during the field works. We are obliged to D.V. Logunov for improving the English of the final draft.

\section{References}

Bhattacharyya T.P. 2002. Taxonomic status of the genus Harpiola Thomas, 1915 (Mammalia: Chiroptera: Vespertilionidae), with a report of the occurrence of Harpiola grisea (Peters, 1872) in Mizoram, India // Proceedings of the Zoological Society, Calcutta. Vol.55. P.73-76.

Borissenko A.V. \& Kruskop S.V. 2003. Bats of Vietnam and Adjacent Territories. An Identification Manual. Moscow: GEOS. 201 p.

Corbet G.B. 1978. The Mammals of the Palaearctic Region: A Taxonomic Review. London: British Museum (Natural History). 314 p.

Corbet G.B. \& Hill J.E. 1992. The Mammals of the Indomalayan Region: A Systematic Review. Oxford: Oxford University Press. 488 p.

Dang Huy Huynh, Dao Van Tien, Cao Van Sung, Pham Trong Anh \& Hoang Minh Khien. 1994. Checklist of Mammals in Vietnam. Hanoi: Publishing House "Science \& Technics". 168 p. [in Vietnamese].

Dao Van Tien. 1985. [Scientific Results of Some Mammal' Surveys in North Vietnam (1957-1971)]. Hanoi: Scientific and Technical Publishing House. 330 p. [in Vietnamese].

Eames J.C. 2002. Eleven new sub-subspecies of babbler (Passeriformes: Timaliinae) from Kon Tum Province, Vietnam // Bulletin of the British Ornithologists' Club. Vol.122. No.2. P.109-141.

Eames J.C., Le Trong Trai, Nguyen $\mathrm{Cu} \&$ Roland Eve. 1999a. New species of barwing Actinodura (Passeriformes: Sylviidae: Timaliinae) from the Western Highlands of Vietnam // Ibis. Vol.141. No.1. P.1-10.

Eames J.C., Le Trong Trai \& Nguyen Cu. 1999b. A new species of laughinghthrush (Passeriformes: Garrulacinae) from the Western Highlands of Vietnam // Bulletin of the British Ornithologists' Club. Vol.119. No.1. P.415.

Geissmann T., Nguyen Xuan Dang, Lormée N. \& Momberg F. 2000. Vietnam Primate Conservation Status Review 2000. Part 1: Gibbons. Hanoi: Fauna \& Flora International, Indochina Programme. 132 p.

Geissmann T., Nguyen Xuan Dang, Lormée N. \& Momberg F. 2003. Status review of gibbons in Vietnam // Asian
Primates. Vol.8. No.3-4. P.10-12.

Groves C.P. 2005. Order Primates // Wilson D.E. \& Reeder D.M. (eds.). Mammals Species of the World. A Taxonomic and Geographic Reference. Third edition. Vol.1. Baltimore: Johns Hopkins University Press. P.111-184.

Grubb P. 2005. Order Artiodactyla // Wilson D.E. \& Reeder D.M. (eds.). Mammals Species of the World. A Taxonomic and Geographic Reference. Third edition. Vol.1. Baltimore: Johns Hopkins University Press. P.637-722.

Heaney L.R. \& Timm R.M. 1983. Systematics and distribution of shrews of the genus Crocidura (Mammalia, Insectivora) in Vietnam // Proceedings of the Biological Society of Washington. Vol.96. No.1. P.115-120.

Hutterer R. 2005. Order Soricomorpha // Wilson D.E. \& Reeder D.M. (eds.). Mammals Species of the World. A Taxonomic and Geographic Reference. Third edition. Vol.1. Baltimore: Johns Hopkins University Press. P.220 311.

Jenkins P.D. \& Smith A.L. 1995. A new species of Crocidu$r a$ (Insectivora: Soricidae) recovered from owl pellets in Thailand // Bulletin of the Natural History Museum, Zoology Series. Vol.61. No.2. P.103-109.

Jenkins P.D. 1982. A discussion of Malayan and Indonesian shrews of the genus Crocidura (Insectivora: Soricidae) // Zoologische Mededelingen, Leiden. Vol.56. P.267-279.

Kruskop S.V., Kalyakin M.V. \& Abramov A.V. 2006. First record of Harpiola (Chiroptera, Vespertilionidae) from Vietnam // Russian Journal of Theriology. Vol.5. No.1. P.15-18.

Kuznetsov V.V. 2006. [Mammals of Vietnam]. Moskva: KMK Scientific Press. 428 p. [in Russian].

Kuznetsov G.V., Borissenko A.V. \& Rozhnov V.V. 2001. [A synopsis of the mammal fauna of the $\mathrm{Vu}$ Quang Nature Reserve] // Korzun L.P. \& Kalyakin M.V. (eds.). [Materials of Zoological and Botanical Studies in $\mathrm{Vu}$ Quang Nature Reserve (Ha Tinh Province, Vietnam)]. Moskva-Khanoi. P.161-189 [in Russian with English summary].

Kuo Hao-Chi, Yin-Ping Fang, Csorba G. \& Ling-Ling Lee. 2006. The definition of Harpiola (Vespertilionidae: Murininae) and the description of a new species from Taiwan // Acta Chiropterologica. Vol.8. No.1. P.11-19.

Lekagul B. \& McNeely J.A. 1988. Mammals of Thailand. Second edition. Bangkok: Saha Karn Bhaet Co. 758 p.

Le Trong Trai, Richardson W.J., Bui Dac Tuyen, Le Van Cham, Nguyen Huy Dung, Ha Van Hoach, Monastyrskii A.L. \& Eames J.C. 1999. An Investment Plan for Ngoc Linh Nature Reserve, Kon Tum Province, Vietnam: A Contribution to the Management Plan. Hanoi: BirdLife International Vietnam Programme. $106 \mathrm{p}$.

Lunde D. \& Nguyen Truong Son. 2001. An Identification Guide to the Rodents of Vietnam. New York: Center for Biodiversity and Conservation, AMNH. 80 p.

Lunde D.P., Musser G.G. \& Nguyen Truong Son. 2003. A survey of small mammals from Mt. Tay Con Linh II, Vietnam with the description of a new species of Chodsigoa (Insectivora: Soricidae) // Mammal Study. Vol.28. No.1. P.31-46.

Lunde D.P., Musser G.G. \& Ziegler T. 2004. Description of a new species of Crocidura (Soricomorpha: Soricidae, Crocidurinae) from Ke Go Nature Reserve, Vietnam // 
Mammal Study. Vol.29. No.1. P.27-36.

Musser G.G. \& Carleton M.D. 2005. Superfamily Muroidea // Wilson D.E. \& Reeder D.M. (eds.). Mammals Species of the World. A Taxonomic and Geographic Reference. Third edition. Vol.2. Baltimore: Johns Hopkins University Press. P.894-1531.

Orlov N.L. 2005. A new species of the genus Vibrissaphora Liu, 1945 (Anura: Megophryidae) from Mount Ngoc Linh (Kon Tum Province) and analysis of the extent of species overlap in the fauna of amphibians and reptiles of the north-west of Vietnam and Central Highlands // Russian Journal of Herpetology. Vol.12. No.1. P.17-38.

Pocock R.I. 1936. The oriental yellow-throated marten (Lamprogale) // Proceedings of the Zoological Society of London. Vol.1936. No.2. P.531-553.

Rozhnov V.V. 1995a. [Taxonomic notes on the yellowthroated marten Martes flavigula] // Zoologicheskii Zhur- nal. Vol.74. No.2. P.131-138 [in Russian with English summary].

Rozhnov V.V. 1995b. Nomenclature note on the name of the genus Lamprogale (Mustelidae: Mammalia) // Lutreola. No.6. P.23-24.

Tate G.H.H. 1941. Results of the Archbold expeditions no. 40. Notes on Vespertilionid bats of the subfamilies Miniopterinae, Murininae, Kerivoulinae and Nyctophilinae // Bulletin of the American Museum of Natural History. Vol.78. P.567-597.

Tordoff A. W., Tran Hieu Minh \& Tran Quang Ngoc. 2000. A Feasibility Study for the Establishment of Ngoc Linh Nature Reserve, Quang Nam Province, Vietnam. Hanoi: BirdLife International Vietnam Programme. $74 \mathrm{p}$.

Yoshiyuki M. 1988. Notes on Thai mammals 1. Talpidae (Insectivora) // Bulletin of the National Science Museum (Tokyo), Series A. Vol.14. P.215-222. 